\title{
Examining the Value of Children in Terms of Family Structure for Families in Northern Cyprus
}

\author{
Başak Eser ${ }^{1}$, Eda Yazgin ${ }^{2}$ \\ Final International University, Faculty of Education, Kyrenia, Northern Cyprus, Basak.eser@hotmail.com \\ Eastern Mediterranean University, Faculty of Education, Famagusta, Northern Cyprus, Eda.yazgin@emu.edu.tr
}

Annotation. In order to shed light on the role of children in today's society, and understand the importance of family relationships, parents are the main instrument, which affects the formation and development of the child, the attitude of the parents to children, helps to more clearly recognize the importance of family relationships. This study investigates the model of the family reflection of today's family changes the way of the family structure is considered as well. The aim of the study is to examine the values parents attribute to their children with regards to culture and family structures.

Keywords: culture, family, family interaction, the value of child.

\section{Introduction}

Family is the smallest social unit in the society. Family is the focal point for the individual in life, an institution made up of the social structure which includes the individual as well as the inter-individual/personal ties. Family system is comprised of the organization of the various roles among the family members. Family is the focus of the society, its basic unit, its oldest and universal institution (Başak, 1997).

The family, established upon local customs, traditions, and laws, is the most basic social institution, formed by parents and children. In order to underline the importance of family for the Turkish society in Northern Cyprus, the 30th article of the Northern Cyprus Constitution states: "Family is the basis of society." 
According to Bilgiseven (1982), the family has an important function regarding the adaptation of the individual to the social context. Societal values and customs are transferred to the children with the aid of the family. The values dominant in the society as 'right' and 'wrong', 'good' and 'bad' are instilled in the consciousness of the individual after being filtered by the family. Family is the most important social institution to serve functions in the socialization of the child.

In the results section of a study by Kağıtçıbaşı (1990), initiated in the late 70s on the value of children, a link between family economic status and the value of children was established. As the family income increases, the economic value and benefit expectations ascribed to the child go down. On the other hand, as the socio-economic level of the family falls, the value, or expectation of any economic benefit, ascribed to the child increases.

Along with social changes, the value ascribed to the child and interfamily relations has begun to change. Studying the value of children in the family has been a valuable tool in measuring social change. For this reason, the study of the value of the children within the context of family relations in Northern Cyprus is deemed to be useful.

The value attributed by parents to their children is important since it provides an understanding of the place and role of children in the society and casts light on human development and family systems as well. Values define what people consider undesirable as well as longed for, chose, and important (Erdem, 2003). Values are dynamic, changeable structures. Especially value priorities may change to meet needs that arise in time. For parents, the value of their children along with changes in inter-generational relations with children, self-development and in the socio-cultural environment are reflected in the setting of parental targets and expectations (Kağıtçıbaşı and Kuşdil, 2000). The significance placed upon children may differ according to the times and society. The society and its values, determining factors such as profession, age, sex, and education are rather influential in determining the differentiation of the significance of children for parents and alteration of commitments.

Another important factor to determine the value of children is their economic status. Economic significance ascribed to children has decreased along with economic developments while the psychological significance of children has increased (Kağıtçıbaşı, 2010). Cultural, psychological, economic changes experienced all over the world have affected parent-child relations as well as value ascribed to children. Authority, mostly experienced in the traditional family, has been replaced with a democratic understanding (Kağıtçıbaşı, 2010). Along with this swift transformation, parenting concept has also changed qualitatively. Reflections of the family change model on the chosen sample in Northern Cyprus form the problem of this study. This paper aims to determine factors directly influential in raising children, along with cultural changes in the family structure, which influence the value ascribed to children. 


\section{Family Change Theory}

The societal traits, factors such as profession, sex, and gender are very influential in determining the value parents ascribe to their children. For example, some children are made to work at a young age to support the family financially while being perceived as a guarantee against old age, where expectations are shaped economically (Arslanoğlu, 2011).

In the Turkish society children of different genders learn gender roles in a different manner because the expectations of families are determined by their children's gender. The family structure, in general, is based on a culture of co-dependence as opposed to the independence of the individuals. As an example, children tend to continue living close to their parents even when they get married (Kağıtçıbaşı, 2000).

Along with industrialization and urbanization, Turkish society has begun to go through a transformation as well. Modernity, along with the migration to the cities, has debilitated the co-dependence relations in the family. In traditional families, democratic understanding has become the dominant understanding, replacing singular authority.

In the Value of Children study (Kağıtçıaşı, 1994), conducted in nine countries including Turkey, three critical values based on Hoffman and Hoffman's (1973) conceptual diagram were defined. These values are:

1 - Economic Value

2 - Psychological Value

3 - Social Value of the Child.

Economic value essentially depends on the material and economic contributions made by children. The child is perceived by the parents as insurance for their later years. Psychological value, on the other hand, is related with emotional satisfaction, such as happiness, pride, joy, and love, the children provide to their parents. The social value of the children is related with the general social recognition acquired by married adults when they have children. The social status obtained by having a boy is related to the continuance of the family name and lineage.

The Value of Children study has provided an understanding of the changes in family and concept of family values and expectations about children in various social strata in different societies where it was conducted. The main dimension of variability has presented itself as socio-economic development (Kağıtçıbaşı, 2010).

The Family Change Theory is based on The Value of Children study. It is a contextual theory that places the self in the family, and the family in the cultural and socio-economic environment. The theory defines three different family models based on relationship patterns: the dependence model, the independence model, and psychologically/emotionally attached family models. The Family Change Theory describes systematic transitions between these models.

In the dependence model, the defining characteristic is material and emotional dependence at both family and individual levels, influencing interpersonal relations. This model is observed in rural, pre-industrial, agricultural and low-income societies. While 
the utilitarian and economic values of the children are the focal points, their insurance function against old age is also in the foreground. In such societies, there is a communal cultural structure.

The defining trait of the independence model is the dominance of material and emotional independence at both family and individual levels. This model is generally present in high-welfare, urbanized, and industrialized societies. While the economic value of children diminishes their psychological value increases. In such cultures, there is an individualistic cultural structure.

Today, along with the socio-economic developments, it is assumed that there will be a complete transition from the dependent model to the independent one. When the continuity of the culture is taken into consideration, however, a third model emerges. This third model is the emotional and/or psychological attachment model. This new model overlaps with the other two in some aspects and differs from them in others. In the third model, while there is emotional co-attachment there is material independence at family and individual levels (Kağıtçıbaşı, 2010).

The second Value of Children study (2003) conducted by Kağıtçıbaşı and Ataca in Turkey also reported findings that support the family change theory. In this study, it was discovered that the economic value of children differs between social strata. While the rural families and those with rural origins and low income underline the economic value of children the urban, medium-high socio-economic status group was the one to prioritize economic value the least. The economic value of the children being important for everyone demonstrates the importance of emotional ties within the family. In the 1975 Value of Children study by Kağıtçıbaşı obedience was the expectation most underlined by the parents among the traits expected from the children; whereas in the second study, it was reported to be among the traits deemed least important. In the 2003 study, independence and self-confidence were reported as desirable traits by the families of urban, medium-high socio-economic status group. This change reflects the emergence of independence in accordance with the psychological-emotional attachment model and supports the family change theory.

The Value of Children study was conducted in Korea, the Philippines, Singapore, Taiwan, Thailand, Turkey, Indonesia, the USA, and Germany. The study involved over 20,000 married couples; issues such as parents' desire about having children, the value they ascribe to their children, and preferences about fertility were examined. In a more recent Value of Children study initiated by Trommsdorff and Nuck, the study was partially replicated (Trommsdorrf \& Nauck, 2005). The same study was also partially repeated by Kağıtçıbaşı and Ataca (Kağıtçıbaşı and Ataca, 2005).

The Value of Children study by Kağıtçıbaşı, initiated in 1982 and called a first by the researcher, was conducted by psychologists, demographers, economists, and other researchers. The total sample size in Turkey consisted of 2300 participants. 
The Value of Children study conducted in Korea indicates a shift from social and economic benefits attributed to children towards psychological benefits attributed (Kim et al., 2005). In the Value of Children study conducted in South Africa, results compatible with the Theory of Family Change were obtained. In addition to a positive relationship between the traditional and utilitarian value of the children and fertility rate, a negative one was established between the psychological value of the children and fertility rate (Sam, Peltzer, Mayer, 2005). In the second Value of Children study conducted in Indonesia in 2005, it was concluded that, regarding the reasons for having children, there has been a shift from traditional to emotional causes. Yet despite these changes, it was also concluded that the value of children as an insurance against old age was still important (Mayer et al., 2005). With the increasing urbanization and economic development in Turkey, the Value of Children study conducted in 2003 reported important variation between the original and second Value of Children studies, supporting the Family Change Theory. It was observed that with the socio-economic changes the economic value of children has decreased while their psychological value grew (Kağıtçıbaşı, 1982).

Grandmothers are more likely to emphasize the importance of economic and social/ familial reasons. For instance, the items "to carry on the family name" and "to have someone to help the family economically" reveal significant generational preference among grandmothers in contrast to the younger generations. The positive VOC among grandmothers, mothers, and teenagers reveals expected generational differences in the conventional economic, emotional and social dimensions in Chinese families. The traditional family value of having children clearly receives greater support among grandmothers followed by mothers and the weakest support among teenagers (Yi \& Chen, 2014).

It has been reported that starting in the 1980s, there has been a proliferation of more serious and larger-in-scale research regarding the studies on family research. The Turkish Family Structure study conducted in 1987 is considered a prominent one. Various other studies were conducted later on following the establishment of Family Research Institution. The Turkish Family Structure study conducted by the State Planning Organization in 1992 and the Family Structure study conducted by the Prime Minister's Office General Directorate of Family and Social Research in 2006 are both remarkable, given their results and scale.

Inglehart's studies, conducted between 1995 and 1997 in over 43 countries, provide the opportunity to deeply analyze a sample representing nearly $70 \%$ of the world's population. The study consisting of the Turkey section of Inglehart's World Values Survey was conducted under the leadership of Esmer (1991) and published as a report by Turkish Industry and Business Association. Turkish Values Survey demonstrates that Turkish people do not fit into any of the traditional, industrial and post-industrial patterns cleanly. In Turkey, it has been observed that phenomena such as family and religion, which are primary elements of traditional society, form the center of societal values. But erosion regarding these values has been observed while a clash between traditional and modern values, regarding socio-economic structure, has been experienced. 


\section{Family Structure in Northern Cyprus}

When the literature on raising children is reviewed, many studies on family research can be found in Turkey and the West while research on family in Northern Cyprus is mostly folkloric. It is observed that most of these studies lack sound family research methodology and a conceptual framework.

In research about family, in order to determine the family structure household members are examined. Historically, in the Turkish Cypriot family structure, the phenomenon of children has carried much weight. Between 1900-1920, it was observed that children were essential for the family (Alicik, 2009). In this period, childless families were generally ostracized and criticized. The child was believed to enhance the family status and protect family integrity. The expectation from girls and boys took the form of helping housework or providing for the family as most families lived in villages. Girls would help with housework while boys contributed to providing for the family. During this era, the concept of 'childhood' was a short-lived phase, one child is expected to promptly transition out of.

Education provided in the family was about the attainment of roles and behaviors aligned with social patterns and norms about gender. In this period education provided in schools heavily involved religion. The aspects of traditional society originating in the family were also experienced at school. Obedience and respect towards the family were at the forefront. A 'utilitarian' approach, along with a communitarian culture, was demonstrated in the society.

In the Northern Cyprus of the 1950s 'childhood' and 'child upbringing' started to be considered a value in the family. In those years "before schooling, children would get used to herding, watering animals and gardens, digging tree roots, plowing, sickling, threshing, whisking olives with carob as it is light" (Adal1, 1997). The school starting age arrives when children become the most important helpers at home. The child is ecstatic about going to school making parents joyous as well. A common phrase families would utter was "Our child should be educated and hence not ignorant as we are". There was seldom any peasant who would wish to refrain from having their children go to school. But as schooling of the children meant more work for the parents, they would be forced to think a lot about this, often against their desires. The child would not rush playing after school but rather come home to work in the field or plains. This situation was caused by the desire to have a higher status in the society in terms of socio-economic status.

In the 1980s and 2000s, according to Alicik (1997), the family in Northern Cyprus went through remarkable structural changes. The difference between the number of one's siblings and that of their children is salient. Having two children appears to be a common pattern for families. There seems to exist a general pattern for families to have two children.

In terms of the gender-based perception of education/higher education, the Northern Cypriot family has also been observed to start ignoring gender distinction. Regarding 
importance attributed to the education of children, it has been observed that with 'knowledge' taking its place in the family as a value, its perception also changed towards something positive from being perceived in negative terms or as mere professional expectation.

The values families wish to transfer to their children presented themselves mainly as 'honesty' and 'responsibility'. In terms of making use of the time spent with children an overwhelming majority seemed to use this time 'watching TV together'.

Monogamy is the most widespread form of matrimony in Northern Cyprus. With the family law coming into force in 1951 polygamy was outlawed. The most widespread form of family in Northern Cyprus is the nuclear family. It can be said that from the $20^{\text {th }}$ century there has been a transition from the patriarchal, meaning father-dominant, family towards egalitarian family, based on the equal authority of parents. It has also been observed that women's role in organizing in-house work, based on traditional values and culture, has continued. On the other hand, owing to increasing levels of education, there has been both qualitative and quantitative increase in the number and status of women in non-domestic economic, cultural, artistic, and educational sectors. This way, women adopt both domestic and non-domestic roles. As the Northern Cyprus Turkish family has changed towards the 'egalitarian family type', based on equal authority, under the influence of modern education and culture the intra-family status of women also tends to become equalized with men (Alicik, 1997). Along with social changes the value ascribed to children in the family and intra-family relations have also begun to change.

The study of the value of the children in the family is perceived as a factor to expose social change. For this reason, studying the value ascribed to children in Northern Cyprus, in the context of changing family structures, was deemed important. The problem of this study is whether the Family Change model is applicable to families in Famagusta district of Northern Cyprus. The sub-problems are the relationship between the state of value ascribed to children by their parents and variable factors such as socio-economic status, age, number of children, education, profession, and place of birth regarding participating families residing in Northern Cyprus.

\section{Methodology}

This study used mixed method research design where both qualitative and quantitative methods are employed. In this study where ordered mixed research method was used, first quantitative data and then qualitative data based on semi-structured interview method was obtained.

\section{Study Sample}

Families residing in Northern Cyprus and with children between 36 and 72 months old formed the sample of this study. The sample was drawn from the parents of children 
attending three public and one private kindergarten placed in the district center and villages of Famagusta, selected using a purposive sampling method.

\section{Table 1}

Background Information on Participating Parents

\begin{tabular}{|c|c|c|c|}
\hline Variables & Groups & $\mathrm{N}\left(\sum \mathrm{N}=412\right)$ & Percentage (\%) \\
\hline Participant & $\begin{array}{l}\text { Mother } \\
\text { Father }\end{array}$ & $\begin{array}{l}248 \\
164\end{array}$ & $\begin{array}{l}60.2 \\
39.8\end{array}$ \\
\hline Age & $\begin{array}{l}20-25 \\
26-30 \\
31-35 \\
36-40 \\
40 \text { and above }\end{array}$ & $\begin{array}{c}2 \\
80 \\
257 \\
51 \\
22\end{array}$ & $\begin{array}{c}0.5 \\
19.4 \\
62.1 \\
12.4 \\
5.3\end{array}$ \\
\hline Place of birth & $\begin{array}{l}\text { Northern Cyprus } \\
\text { Turkey } \\
\text { Other }\end{array}$ & $\begin{array}{c}317 \\
88 \\
7\end{array}$ & $\begin{array}{c}76.9 \\
21.4 \\
1.7\end{array}$ \\
\hline $\begin{array}{l}\text { Period of } \\
\text { Residence } \\
\text { in Northern } \\
\text { Cyprus }\end{array}$ & $\begin{array}{l}0-5 \text { years } \\
6-10 \text { yrs } \\
11-15 \mathrm{yrs} \\
16-20 \mathrm{yrs} \\
21-25 \mathrm{yrs} \\
26-30 \mathrm{yrs} \\
30 \text { and above }\end{array}$ & $\begin{array}{c}9 \\
20 \\
12 \\
12 \\
13 \\
18 \\
328\end{array}$ & $\begin{array}{c}2.2 \\
4.9 \\
2.9 \\
2.9 \\
3.2 \\
4.4 \\
79.6\end{array}$ \\
\hline $\begin{array}{l}\text { Level of } \\
\text { Education }\end{array}$ & $\begin{array}{l}\text { Primary education } \\
\text { High school } \\
\text { College } \\
\text { University } \\
\text { Master's Degree } \\
\text { Doctorate Degree }\end{array}$ & $\begin{array}{c}20 \\
109 \\
9 \\
242 \\
21 \\
11\end{array}$ & $\begin{array}{c}4.9 \\
26.5 \\
2.2 \\
58.7 \\
5.1 \\
2.7\end{array}$ \\
\hline Job & $\begin{array}{l}\text { Public servant } \\
\text { Self-employed } \\
\text { Laborer } \\
\text { Unemployed } \\
\text { Housewife }\end{array}$ & $\begin{array}{c}173 \\
198 \\
13 \\
2 \\
26\end{array}$ & $\begin{array}{l}42.0 \\
48.1 \\
3.2 \\
0.5 \\
6.3\end{array}$ \\
\hline Income rate & $\begin{array}{l}\text { 1000-2000 Turkish Lira } \\
2001-3000 \text { TL } \\
3001-4000 \text { TL } \\
4001-5000 \text { TL } \\
5001 \text { and above }\end{array}$ & $\begin{array}{c}22 \\
26 \\
72 \\
89 \\
203\end{array}$ & $\begin{array}{c}5.3 \\
6.3 \\
17.5 \\
21.6 \\
49.3 \\
\end{array}$ \\
\hline
\end{tabular}




\section{Data Collection Tools}

One of the data collection tools used for this study was the questionnaire about age, education, income levels, etc. of participating parents, filled in anonymously. In this study, in order to examine the reasons for having children and value ascribed to children, the Value of Children Scale (Kağıtçıbaşı, 1982) was used. The Value of Children Scale measures 'economic', 'social' and 'psychological' value of children, as three sub-dimensions, with 27 Likert-type items. The Cronbach alpha coefficients were calculated as .77 for social value, .82 for economic value, and .80 for psychological value (Kağıtçıbaşı, 1982; Kağıtç̧ıbaşı and Ayçiçeği, 2010). In order to obtain qualitative data semi-structured interviews, based on experts' views, were conducted with participating parents about 'being parents.

\section{Process}

Interviews were conducted with 50 participants, 40 mothers and 10 fathers, sampled with a purposive sampling method. Data were collected from a total of 436 participants who filled in the parent information form and Value of Children Scale. After the investigation of the 436 data points, only 412 were analyzed further as other questionnaires were found invalid (failed to finish questionnaires or scales, chose multiple answers for each item, etc.).

\section{Data Analysis}

SPSS 22 software was used for quantitative data analysis. For the items studying differences of factor points according to demographic characteristics, a t-test was used when a number of groups was 2 and for others variance analysis (ANOVA) was used. If ANOVA results were significant $(\mathrm{p}<.05)$ then homogeneity of variances was taken into consideration to find inter-group differences.

Descriptive analysis and content analysis techniques were used in the analysis of qualitative data. Descriptive analysis is a technique where the data obtained is summarized and interpreted according to pre-established themes, direct quotes are used frequently in order to reflect the views of interviewees in a dramatic way and results are interpreted within the framework of a cause-result relationship (Yıldırım \& Şimşek, 2003). The descriptive analysis technique was implemented using three efficiency steps (decrease data, present data, reach results, and confirm) (Türnüklü, 2000). Regarding the presentation of the data, criteria such as standing out (dissenting view), explanatory power (aligned with the theme), diversity, and being an extreme example were taken into consideration when selecting quotes to be displayed (Ünver et al., 2010).

In this research, the agreement percentage formula was used to determine reliability in content analysis. The agreement percentage is calculated using [Reliability $=$ (Consensus/ (Consensus+Divergence)x100] formula (Miles and Huberman, 1994). According to Yıldırım and Şimşek (2003), when the convergence percentage is at 70\%, reliability is 
generally achieved. In this study, the convergence percentage using this formula in coding was $90 \%$ for item $1,85 \%$ for item $2,95 \%$ for item 3, 94\% for item $4,86 \%$ for item $5,90 \%$ for item $6,98 \%$ for item $7,88 \%$ for item 8 and general convergence level for all items was calculated as 90\% (Yıldırım \& Şimşek, 2003).

\section{Data and Interpretation}

Table 2

Value of Children According to Parents

\begin{tabular}{lcccccc}
\hline \multicolumn{1}{c}{ Participant } & N & X & S & o & t & p \\
\hline Mother & 248 & 75.75 & 9.55 & 410 & .097 & .923 \\
Father & 164 & 75.65 & 10.25 & & & \\
\hline
\end{tabular}

$\mathrm{p}<.05$

Results of t-test analyses conducted in order to compare parents' value ascriptions to their children demonstrate that there is no statistically significant difference between views of parents, $\mathrm{t}(410)=.097 \mathrm{p} \geq .923$.

Table 3

Value of Children According to the Birthplace of Mothers

\begin{tabular}{lllcc}
\hline & (I) Place of birth & (J) Place of birth & Average difference $(\mathbf{I}-\mathbf{J})$ & $\mathbf{p}$ \\
\hline \multirow{3}{*}{ Economic } & Northern Cyprus & Turkey & $-1,2557^{*}$ & .011 \\
& & Other &, 73072.80 & .810 \\
& \multirow{2}{*}{ Turkey } & Northern Cyprus & $1,2557^{\star}$ & .011 \\
& & Other & 1,9864 & .240 \\
\cline { 3 - 5 } Social & \multirow{2}{*}{ Northern Cyprus } & Turkey & $-2,2253^{*}$ & .008 \\
& & Other & $-0,4844$ & .969 \\
& \multirow{2}{*}{ Turkey } & Northern Cyprus & $2,2253^{*}$ & .008 \\
& & Other & 1.7409 & .690 \\
\hline $\mathrm{p}<05$ & & & \\
\end{tabular}

The results of One-Way Variance Analysis (ANOVA) applied to the mothers' scores, allocated according to the mothers' birthplace, on Value of Children Scale show that there is no significant relationship between the birthplace of the mother and sub-dimension "psychological value" ( $p>.05)$. But there is a difference between scores mothers received on the "economic value" and "social value" sub-dimensions according to their birthplace as Northern Cyprus (TRNC) or Turkey ( $\mathrm{p}>.05)$. Economic value was higher for mothers born in Turkey (TR), while those born in Northern Cyprus (TRNC) underlined the social value of their children. 
Table 4

The Value of the Child According to the Educational Level of Mothers

\begin{tabular}{lllcc}
\hline & $(\mathbf{I})$ Level Of Education & (J) Level Of Education & $(\mathbf{I}-\mathbf{J})$ & $\mathbf{p}$ \\
\hline \multirow{2}{*}{ Economic } & Primary education & High school & 2.80 & .032 \\
& & University & 3.52 & .001 \\
& & Master's Degree & 3.65 & .010 \\
\multirow{2}{*}{ Social } & Primary education & High School & 6.80 & .000 \\
& & College & 9.86 & .006 \\
& & University & 7.20 & .000 \\
& & Master's Degree & 7.08 & .001 \\
& & Doctor's Degree & 8.36 & .008 \\
\hline
\end{tabular}

Table 5

Anova Results of Child Value Scale Scores According to Mother Education Levels

\begin{tabular}{lccccc}
\hline \multicolumn{1}{c}{ Variance } & Sum of square & $\boldsymbol{\sigma}$ & Mean Square & F & P \\
\hline Intergroup & 1803,61 & 5 & 360.723 & 4.220 & .001 \\
In groups & 20683,870 & 242 & 85.471 & & \\
Total & 22487,484 & 247 & & & \\
\hline
\end{tabular}

$\mathrm{p}<.05$

The results of One-way Variance Analysis (ANOVA) using the scores mothers received based on their answers, according to the level of education of mothers, show that there is no significant relationship between the level of education of mothers and scores they received on the "psychological value" sub-dimension ( $p>$.05). But significant relationships between the level of education and scores on "economic value" and "social value" sub-dimensions were found ( $p>$.05). As the level of education of mothers rises, economic and social values ascribed to children become insignificant. It can be said that the level of education is an important factor in determining social and economic value ascribed to children.

Table 6

Anova Results Regarding the Mothers' Length of Residence in Northern Cyprus

\begin{tabular}{lcccc}
\hline & Northern Cyprus & $\mathbf{N}$ & $\mathbf{X}$ & $\mathbf{s}$ \\
\hline Economic & $0-5$ years & 5 & 8.20 & 3.63 \\
& 26-30 years & 8 & 14.25 & 3.01 \\
Psychological & $0-5$ years & 5 & 42.00 & 7.42 \\
& 26-30 years & 8 & 50.87 & 9.03 \\
Social & $0-5$ years & 5 & 18.20 & 4.71 \\
& 26-30 years & 8 & 26.75 & 8.06 \\
\hline
\end{tabular}


Table 7

Value of Child According to Mother's Life in Northern Cyprus

\begin{tabular}{lcccc}
\hline & (I)Northern Cyprus & (J)Northern Cyprus & Average difference & $\mathbf{p}$ \\
\hline Economic & $0-5 \mathrm{yrs}$ & $21-25 \mathrm{yrs}$ & -5.80 & .00 \\
& & $26-30 \mathrm{yrs}$ & -6.05 & .00 \\
\multirow{3}{*}{ Social } & $26-30 \mathrm{yrs}$ & $0-5 \mathrm{yrs}$ & 8.55 & .02 \\
& & $6-10 \mathrm{yrs}$ & 6.44 & .04 \\
& & $16-20 \mathrm{yrs}$ & 8.17 & .01 \\
& & 30 ve above & 8.92 & .00 \\
\hline
\end{tabular}

$\overline{\mathrm{p}}<.05$

Table 7 shows that mothers who have lived in Northern Cyprus for 0-5 years ascribe less economic value to their children than those who have lived there for 21-25 or 26-30 years. It can be seen that the economic value of children and the length of residence are correlated. Scores received on 'social value' of children are higher for the group of mothers who have lived in Northern Cyprus for 26-30 years. The 'psychological value' of children appears not to depend significantly on the mothers' length of residence in Northern Cyprus.

Table 8

Value of Children According to the Mother's Age

\begin{tabular}{llccc}
\hline & \multicolumn{1}{c}{ Age range } & N & X & s \\
\hline Psychological & 26-30 years & 51 & 49.16 & 5.07 \\
& 31-35 years & 155 & 46.35 & 5.20 \\
& 36-40 years & 30 & 46.16 & 5.24 \\
& 40 years and above & 12 & 46.16 & 4.04 \\
Social & 26-30 years & 51 & 20.06 & 4.91 \\
& 31-35 years & 155 & 18.24 & 4.11 \\
& 36-40 years & 30 & 17.86 & 3.83 \\
& 40 years and above & 12 & 16.83 & 3.53 \\
\hline
\end{tabular}

On the 'psychological value' sub-dimension, it can be said that the points received by mothers of ages 26-30 on the Value of Children Scale demonstrate a significant difference regarding their views $(\mathrm{x}=49.16)$. On the 'social value' sub-dimension, mothers of 26-30 age group differs from mothers in other age groups significantly, regarding social value they ascribe to their children $(\mathrm{x}=20.06)$. 
Table 9

Value Ascribed to Children and Level of Income

\begin{tabular}{rccc}
\hline (I)Income & $(\mathrm{J})$ Income & Average difference (I-J) & $\mathbf{p}$ \\
\hline $1000-2000 \mathrm{TL}$ & $3001-4000 \mathrm{TL}$ & 11.99 & .000 \\
& $4001-5000 \mathrm{TL}$ & 10.30 & .000 \\
& $5001 \mathrm{TL}$ and above & 10.054 & .000 \\
\hline $\mathrm{p}<.05$
\end{tabular}

Table 10

Anova Results of Value of Children Scale Scores According to Family Income Level

\begin{tabular}{lccccc}
\hline \multicolumn{1}{c}{ Variance } & Sum of Square & $\boldsymbol{\sigma}$ & Mean Square & F & P \\
\hline Intergroup & 3362,071 & 4 & 840.518 & 9.445 & .00 \\
In groups & 36219,803 & 407 & 88.992 & & \\
Total & 39581,874 & 411 & & & \\
\hline
\end{tabular}

One-Way Variance Analysis (ANOVA) of scores based on the level of total monthly income shows that there are significant relationships between the total monthly income of the family and 'economic' and 'social' value sub-dimensions ascribed by parents. According to the views of parents with a monthly income of 1000-2000 TL, economic, social, and psychological value of children constitutes a significant difference and value ascribed to children in general tend to increase.

When we look at scores of fathers on the value of children scale according to the father's level of education, we see that as the level of education of fathers increases, the economic and social value of children decreases. On the other hand, father's level of education doesn't make a difference regarding the psychological value of children.

Table 11

Value of Children According to Father's Profession

\begin{tabular}{cccc}
\hline \multicolumn{1}{c}{$(\mathbf{I}) \mathbf{J o b}$} & \multicolumn{1}{c}{ (J) Job } & Average difference $(\mathbf{I}-\mathbf{J})$ & $\mathbf{p}$ \\
\hline Laborer & Public officer & 12.52 & .00 \\
& Self-employed & 15.67 & .00 \\
\hline $\mathrm{p}<.05$ & & &
\end{tabular}

Table 11 shows that the relationship between the father's level of education and the value ascribed to children is more significant for fathers who work as laborers, compared to both fathers who work as public officers and those who work in commerce. 
Table 12

Anova Results on Relationship Between Value of Children and Number of Children Parents Have

\begin{tabular}{lccccc}
\hline \multicolumn{1}{c}{ Variance } & Sum of Square & $\boldsymbol{\sigma}$ & Mean Square & F & P \\
\hline Intergroup & 4408.769 & 4 & 1102.192 & 12.754 & .00 \\
In groups & 35173.105 & 407 & 86.420 & & \\
Total & 39581.874 & 411 & & & \\
\hline $\mathrm{p}<.05$ & & & &
\end{tabular}

According to the Value of Children Scale, as the number of children parents have increased, so does the economic, social, and psychological value they ascribe to their children. A positive relationship was found between a number of children and the value ascribed to children.

Content analysis was applied to the data obtained after interviews with 50 parents. The resulting category and themes are listed below. data

Category and themes emerging after content analysis applied to qualitative

1. Views on being a mother/father

1.1. Intra-family roles

2. Views on the reasons behind the desire to have children

2.1. Family concept

2.2. Individual factors

3. Views on expectations from children

3.1. Individual qualities

3.2. Family concept

4. Views on the personality of child

4.1. Individual qualities

5. Views on how time is spent with the child

5.1. Domestic activities

5.2. Non-domestic activities

6. Views on parents having the responsibility of the child

6.1. Mother

6.2. Father

6.3. Shared responsibility

7. Views on the context to raise children

7.1. Family

8. Views on values desired to be transferred to the child

8.1. Individual qualities

8.2. Family values 
Regarding the data obtained at the interviews, the identities of the participants have been concealed and a coding standard was used instead. Among the participants, the mothers were denoted with 'A' and the fathers with ' $B$ ', and the code for each participant was determined as i.e. 'A1, A2, A3, A4, A5'.

Views on motherhood/fatherhood: The related item in the interview form was worded as "In your view, what is motherhood/fatherhood?". When the views of participants were studied the sub-theme of intra-family roles emerged. Upon the study of this sub-theme it was found that sacrifice and unrequited love were underlined by mothers regarding motherhood. Fathers were instead found to underline trust and support.

Views on the reasons behind the desire to have children: The related item in the interview form is worded as "What is the reason for you to desire to have children?". Two sub-themes emerged when the views of participants were studied: the concept of family and individual factors. The most important view mentioned by the parents interviewed was 'becoming a family'.

Views on expectations from the children: The item directed at this sub-problem was worded as "What are your expectations from your child when (s)he grows up?". Two sub-themes were identified upon the study of the views of participants. These were individual traits and the concept of family. When these two sub-themes were studied, the views by the parents emerged as the individual qualities they wanted their children to have (successful, well-mannered, respectful, self-confident, etc.) and the concept of family (knowledgeable about family values).

Views on the personality of the child: The item directed at this sub-problem in the interview form was worded as "what sort of personality would you like your child to develop?". This item was asked as an explanatory one regarding the parents' expectations from their children. Parents' general expectations from their children and those about their future personalities were, to a large extent, observed to converge. Mother participants, expressing views about individual qualities (self-confident, mannered, respectful, outgoing, loving, honest, and not giving up) and the concept of family (knowledgeable about family values and traditions), converged to a large extent. Another trait underlined by the father participants was "not giving up, taking a tough stance in the face of injustice" in addition to those mentioned by mother participants.

While one of the father participants expressed his views as "I would like him/her to be an individual with self-confidence. I want him/her to put a brave face against injustice." (B5, father to a 4-year old boy, college graduate, government officer) another father participant said "he should have high self-confidence. He should stand still against injustice. I would like him to be respectful and well-mannered." (B7, father to a 3-year old boy, college graduate, government officer).

Views on how time is spent with the child: The interview form item related with this sub-problem was worded as "How do you spend time with your child/what do you do together?". Two sub-themes emerged upon analyzing the views of the participants. 
These were domestic and non-domestic activities. After studying these two sub-themes, it was concluded that most underlined activities were playing together and going to the playground. In addition, parents reported that they were able to spend time with their children mostly at the weekends.

Views on mothers/fathers having responsibility for the children: The interview form item related with this sub-problem was worded as "Who is mostly responsible in the family for the development and education of your child?". When participant views were analyzed three sub-themes emerged. These sub-themes were the responsibility of mother or father, or co-responsibility. The most significant view expressed by parents was that children's responsibility was mostly upon the mother.

Views on the best environment to raise the child: The interview form item related with this view was worded as "In your view, what is the best environment to raise a child?". One sub-theme emerged when the participant views were studied: family environment. The view expressed by the interviewed parents as the most important factor was the family.

Views on the values desired to be transmitted to the child: The interview form item related with this view was worded as "What are the values you wish to transfer to your child?". Two sub-themes emerged upon studying the views of the participants. These themes were family values and individual values. The values deemed most important by the interviewed parents were; committing to family/having strong family ties and their child is an individual full of love, respect, and commitment to traditions. The value perception of the parents living in Northern Cyprus and making up the sample for this study was also determined with this question.

\section{Conclusions}

The result of this study on the value of children, conducted in the Famagusta district of Northern Cyprus with 412 mothers and fathers, demonstrates that views of parents about being a parent are based on principles of sacrifice, trust, and support. While mothers underline sacrifice and unrequited love, fathers are focused on trust and support. Given these results, it can be said that mother and father roles in Northern Cyprus are distinctly set apart. As the intra-family roles become more and more different, so do the expectations about gender. It has been determined that the primary reason behind the desire for having a child is 'becoming a family', in addition to other reasons stated such as loving the child and the desire to provide for the child. This finding indicates the social value of the child as stated in Hoffman and Hoffman's (1973) conceptual diagram. The perception of having a child as a factor in the social status and complementing becoming a family is related to the social value of the child. It can be concluded that expectation of participating parents from their child was mostly about the child being respectful, successful and knowledgeable about family values in addition to sustaining them. 
Parents also reported that they expected their child to appreciate their sacrifices made for them and have their affections returned in their old age. The economic value of the child, in addition to the psychological value, has also been another remarkable finding of this study. Regarding expectations about the personality of the child, the expectation about the child to become an individual with self-confidence and again reflecting family values are placed at the forefront. Similar results regarding expectations from children were achieved at the second Value of Child study, conducted by Kağıtçıbaşı and Ataca (2003) in Turkey. Unlike the first study conducted in 1975 where obedience was deemed most important, self-confident and outgoing personality have become more important in time. Similar results were achieved in Northern Cyprus. It has been determined that parents play with their children at home and outside and they participate in activities such as going to the playground, travelling and they attend parties/celebrations. It has also been determined that mothers are mostly responsible for nurturing their children. This result draws attention to the role of women in the family in Northern Cyprus. It is also thought to be parallel with mothers defining motherhood as 'sacrifice'. It was identified that families had expectations regarding the transfer of family values to their children and their children sustaining these values. A consensus on the psychological value of the child was also identified.

Looking at the relationship between variables about family structures and value ascribed to the child, it was determined that value of the child does not depend greatly on being a mother or father. The variables that significantly influence the value ascribed to their child by parents were level of education of both parents, their length of residence in Northern Cyprus, age of mother, profession of father, income level, and number of children. It was identified that psychological value of the child increased along with the level of education of both mother and father. It was also determined that the value ascribed to the child differs according to the mother's birthplace, as Turkey or Northern Cyprus. While economic value seems to be higher for mothers born in Turkey, social value is higher for mothers born in Northern Cyprus. However, as a mother lives in Northern Cyprus for longer, the social value they ascribe to the child appears to increase in a manner that reflects the general result and observations. The age of the mother was also discovered to be significantly related with the value ascribed to the child. It was observed that as the number of children increases so does the value ascribed to the child. The number of children being determined by families as around one or two is also in line with the Family Change Theory. The fertility preference of families is influenced by the desire to have as many children as one can afford and values such as the ascending status of the women. The dominance of families with a nuclear family structure and one or two children is another finding of this study which is in line with Family Change Theory.

It was determined that generally the value most ascribed to the child is the psychological value. In this regard, the findings of this study are consistent with other studies. The Value of Child study conducted in Korea determined that there is a shift from social 
and economic value towards psychological value ascribed to the child (Kim et al., 2005). Results consistent with Family Change Theory were also attained in the Value of Child study conducted in South Africa. While a positive relationship between the utilitarian and traditional value of the child and fertility was found, a negative one was established between psychological value of the child and fertility (Sam, Peltzer and Mayer, 2005). In the second Value of Child study conducted in Indonesia (2005) the reasons for having a child were reported to be shifting from traditional towards more emotional ones. But despite this, the importance of value of the child as an insurance against old age seemed to continue (Mayer et al., 2005). In the study conducted by Hu and Chiang (2020) in Taiwan, while young adults do not see economic benefit as the primary value for having children, economic resources significantly shape their desire to have children. In addition, it is observed that the preference of male children has largely been overturned. In the study it was concluded that contemporary parents ascribe psychological value to their children while they expect their children to continue and sustain their values and take care of them in their old age. According to the results of the research conducted in Indonesia in 2020; while the psychological benefits of having children are highlighted, the view that children provide psychological security-care and friendship-in old age has also been emphasized (Utomo et al., 2020). Lim and Chung conducted research on the value of children in Korea in 2015. The purpose of this study was to examine the value of children in South and North Korea and to identify the similarities and differences in value orientations related to children and curriculum in child-care and education. Results showed that first, it was common that both of social and psychological values of children were found, but the psychological values were more prevalent in the South and the social values were more dominant in the North (Lim \& Chung, 2015).

Kağıtçıbaşı underlines the fact that studies conducted in different cultural settings will shed light on the diversity in parental value and actions. Studies to be conducted in the Cypriot society on similar issues such as culture, parenting, and parent-child relations are of great importance since the island receives a significant number of immigrants and thus has been turning into a multi-cultural society. The Value of Child study conducted by Kağıtçıbaşı in 1970s became the basis of the Family Change Theory, whose results form the basis of this study. This theory determines three prototypical family models. One is the 'dependent family model', the second one is the 'independent family model' and the third is the 'psychological emotional attachment model'. For example, Kağıtçıbaşı (2012) states that in communitarian societies with a culture of solidarity, such as Turkey, there is no transition from the traditional dependent family model to the independent family model while the third one is in a state of emergence. She defends the view that during this process in families, psychological dependence continues while material dependence is in decline. The findings of this study, though limited to the sample in Northern Cyprus, are consistent with the 'psychological dependence model'. When qualitative and quantitative findings are analyzed it can be concluded that the psychological value of the 
child in Northern Cyprus is maintained by the parents. Current literature on the value of children shows that as societies modernize, parents move from privileging economic benefits to emotional satisfaction in child rearing (Arnold et al., 1975; Trommsdorff \& Nauck, 2005; Yi \& Chen, 2014). The extra-low fertility in Taiwan, Despite the popularity of the economic approach in explaining the fall in fertility, social and psychological factors are still considered to affect young adults' decisions upon marriage and parenthood. The varying values attached to children have been documented as crucial reasons for having or not having children (Chen, \& Yi, 2021).

The fact that grown-up, even married, children live with or close to their parents in Northern Cyprus also indicates the psychological value of the child. It has been observed that despite the disappearance of material expectations, emotional dependence continues. It is assumed that the psychological value of the child is fostered with cultural transfer and the sustainment of family values.

Future studies may cover the entirety of the island. This way, the generalization of findings and linking them with theory might be bolstered. Taking the multi-cultural structure of Northern Cyprus into consideration, studies to be conducted with participants born and living in Cyprus may provide clearer findings that test the predictions of the theory.

\section{References}

Adalı, K. (1997). Dağarcık [Repository]. Işıık Kitabevi.

Alicik, H. (1997). Kıbrıs Türk aile yapısı [Tukish Cypriot family structure]. Işık Kitabevi.

Arnold, F., Bulatao, R. A., Buripakdi, C., Chung, B. J., Fawcett, J. T., Iritani, T., Lee, S. J., \& Wu, T. S.

(1975). The value of children: A cross-national study. East-West Center.

Arslanoğlu, İ. (2005). Türk değerleri üzerine bir değerlendirme [An evaluation on Turkish values]. Felsefe Dünyası Dergisi. 3-4, 64-77.

Başak, O. (1997). Aile dinamikleri [Family dynamics], Aile Hekim Dergisi, 1(3), 181-186.

Bilgiseven, K. A. (1982). İktisat sosyolojisi açısından eğitim yolu ile kalkınmanın esasları [Principals of development through education in terms of economic sociology]. Divan Yayılar1.

Chen, YH., \& Yi, CC. (2021). An exploration of individual, familial, and cultural factors associated with the value of children among Taiwanese young adults. Child Indicators Research, 14, 487510. https://doi.org/10.1007/s12187-020-09794-w

Erdem, F. (2003). Sosyal bilimlerde güven [Trust in social sciences]. Vadi Yayınları.

Hoffman, L. W., \& Hoffman, M. L. (1973). The value of children to parents. Psychological perspectives on education. Basic Books.

Hu, L., \& Chiang, Y. (2020). Having children in a time of lowest-low fertility: Value of children, sex preference and fertility desire among Taiwanese young adults. Child Indicators Research, 14, 537-554. https://doi.org/10.1007/s12187-020-09753-5

Inglehart, R. F. (1997). Modernization and postmodernization, Princeton University Press. 
Kağıtçıbaşı, Ç. (1982). The changing value of children in Turkey. Current studies on the value of children. 60, papers of the East West Population Institute, Honolulu, US.

Kağıtçıbaşı, Ç. (1990). Insan aile kültür [Human family culture]. Remzi Kitabevi.

Kağıtçıbaşı, Ç. (1994). Handbook of cross cultural psychology: Social behaviour and applications, 3, Allyn \& Bacon.

Kağıtçıbaşı, Ç. (2000). Günümüzde insan ve insanlar [Human and people in our age\}. Evrim Yayınlar1.

Kagitcibasi, C., \& Ataca, B. (2005). Value of children and family change: A Three-decade portrait from Turkey. Applied Psychology, 54, 317-337. https://doi.org/10.1111/j.1464-0597.2005.00213.x Kağıtçıbaşı, Ç. (2007). Kültürel Psikoloji [Cuntural psychology]. Evrim Yayınları.

Kağitçibaşi, Ç. (2010). Benlik aile ve insan gelişimi [Self family and human development]. Koç Üniversitesi Yayınları.

Kim, U., Park, Y.-S., Kwon, Y.-E., \& Koo, J. (2005). Values of children, parent-child relationship, and social change in Korea: Indigenous, cultural, and psychological analysis. Applied Psychology, 54, 338-354. https://doi.org/10.1111/j.1464-0597.2005.00214.x

Lim, J., \& Chung, S. (2015). The value of children in South and North Korea. Journal of Korean Home Management Association, 33 (77-95). https://doi.org/10.7466/JKHMA.2015.33.6.77

Miles, M. B., \& Huberman, A. M. (1994). Qualitative data analysis (2nd ed.). Thousand Oaks. Ca: Sage Publications.

Sam, D., Peltzer, K., \& Mayer, B. (2005). The changing values of children and preferences regarding family size in South Africa, Applied Psychology: An International Review, 54(3), 355-377. http://hdl.handle.net/20.500.11910/6688

Trommsdorff, G., \& Nauck, B. (2010). Introduction to special section for journal of cross-cultural psychology: Value of children: A concept for better understanding cross-cultural variations in fertility behavior and intergenerational relationships. Journal of Cross-Cultural Psychology, 41(5-6), 637-651. https://doi.org/10.1177/0022022110373335

Trommsdorf, G., Kim, U., \& Nauck, B. (2005). Factors influencing value of children and intergenerational relations in times of social change: Analyses from psychological and sociocultural perspectives: Introduction to the special issue. Applied Psychology, 54. 313-316. https://doi.org/10.1111/j.1464-0597.2005.00212.x

Türnüklü, D. A. (2000). Eğitimbilim Araştırmalarında Etkin Olarak Kullanılabilecek Nitel Bir Araştırma Tekniği: Görüşme [A qualitative research technique that can be used effectively in educational research: Interview]. Kuram ve Uygulamada Ĕ̆itim Yönetimi, 24 (24), 543-559. https://dergipark.org.tr/tr/pub/kuey/issue/10372/126941

Utomo, A. J, McDonald, P., Utomo, I. D., \& Hull, T. H. (2020). Do individuals with higher education prefer smaller families? Education, fertility preference and the value of children in Greater Jakarta. Child Indicators Research, 1-30. https://doi.org/10.1007/s12187-020-09752-6 Ünver, G., Bümen, N. T., \& Başbay, M. (2010). Ortaöğretim Alan Öğretmenliği Tezsiz Yüksek Lisans Derslerine Öğretim Elemanı Bakışı [Instructor's perspective on secondary education field teaching non-thesis master's courses], Eğitim ve Bilim Dergisi, 155 (35), 63-77. 
Yıldırım, A., \& Şimşek, H., (2003). Sosyal bilimlerde nitel araştırma yöntemleri [Qualitative research methods in social sciences ]. Seçkin Yayınları.

Yi, C. C., \& Chen, Y. H. (2014). The intergenerational transmission of the value of children in contemporary Chinese families: Taiwan and mainland China compared. Comparative Population Studies, 39(4), 679-706. https://doi.org/10.12765/CPoS-2014-14

\title{
Vaiko vertès tyrimas skirtingose šeimos struktūrose Šiaurès Kipre
}

\author{
Başak Eser ${ }^{1}$, Eda Yazgin ${ }^{2}$
}

Tarptautinis universitetas, Edukologijos fakultetas, Kirenija, Šiaurès Kipras, Basak.eser@hotmail.com

Rytų Viduržemio jūros universitetas, Edukologijos fakultetas, Famagusta, Šiaurès Kipras, Eda.yazgin@emu.edu.tr

\section{Santrauka}

Šiame straipsnyje taikant mišrų tyrimo metodą analizuojamas „Šeimos pokyčių modelis“ Šiaurès Kipro šeimose. Tyrimo tikslas - ištirti vaikui priskiriamą vertę šeimoje, atsižvelgiant $\mathfrak{i}$ kintančią kultūrą ir šeimos sandarą, t. y. ̣̂vertinti tiesioginị šeimos kultūrinės transformacijos ir šeimos struktūrų poveikị vaikams ir tiksliai nustatyti atitinkamą vaiko vertę šeimoje. Imtị sudarè 412 tèvų, auginančių vaikus nuo 36 iki 72 mènesių. Vaikai lankè tris skirtingas valstybines ir vieną privačią ikimokyklines ịstaigas Famagustoje ir jos apylinkèse. Tẻvų priskiriama vertė vaikui buvo vertinama pagal šiuos tėvų kintamuosius: amžių, išsilavinimo lygị, ekonominę padèti, profesiją, aplinką, kurioje jie augo.

Tyrimas buvo atliktas remiantis Çiğdem Kağıtçıbaşı sukurta „Šeimos pokyčių teorija“. Tyrime taikytas mišrus tyrimo metodas, apimantis tiek kiekybines, tiek kokybines paradigmas. Duomenims rinkti buvo naudojamas „Vaiko vertės klausimynas“ ir pusiau struktūrizuoti interviu. Tyrimo rezultatai atskleidè, kad vaiko psichologinè ir socialinė vertė Šiaurès Kipro šeimose buvo labai aukšta, o šeimos išsilavinimo lygis, socialinè-ekonominė ir kultūrinè padètis buvo nustatyti kaip svarbūs veiksniai.

Esminiai žodžiai: kultūra, šeima, bendravimas šeimoje, vaiko vertè. 